Wojciech M. Marchwica, Jagiellonian University, Institute of Musicology Golebia str. 24, 31-07 Krakow, Poland

\title{
METHODS OF THE MUSIC POPULARIZATION AMONG CHILDREN AS THE IMPORTANT FACTOR OF FIGHTING AGAINST THE MCDONALDISATION OF GLOBAL CULTURE
}

Globalization and the related popularization of artistic tastes is a process that cannot be taught directly. It is possible and necessary to shape higher aesthetic expectations than those provided by the commercialized entertainment market. An important role is played by artistic education — including music especially and not by professional musicians, but by general education - reaching the majority of society. Art schools and music majors at art colleges should prepare their graduates for educational activities and provide them with tools for shaping common tastes. A separate issue is to educate decision-makers and parents how important music is for development of a child. Music is not an "entertainment for elites", but an important element of shaping psycho-individuality and intellectual ability of children and teens.

Key words: methods of the music popularization, global culture, music education.

\section{Марквіца Войцех}

Засоби популяризації музики серед молоді як важливий фактор протидії «макдональдизації» глобалізованої культури

Популяризацію мистецьких смаків як процес нині не можна вивчати поза проблемами глобалізачії. Враховуючи погляди сучасної молоді на так звану «класичну музику», видається необхідним формувати більш високі естетичні запити молодого покоління, ніж ті, що забезпечуються комерційним розважальним ринком. Важливої ролі у цьому процесі набуває мистецька освіта, зокрема музична, - не стільки виховання професійних музикантів, як загальна музична освіта у школі, що доступна більшості громадян. Дитячі школи мистецтв та музичні класи в мистецьких коледжах мають готувати випускників до навчальної діяльності, забезпечувати їх інструментами подальшого формування суспільних мистецьких смаків. Не менш важливим є навчити батьків та відповідальних осіб того, наскільки важливим є музичне мистецтво для розвитку дитини. Такими, здавалося б, простими, але дієвими засобами можливо сформувати загальне усвідомлення того, що музика є не «елітарною розвагою», а важливим елементом формування індивідуальності та інтелектуальних здібностей сучасних дітей та підлітків.

Ключові слова: засоби популяризачії музики, глобальна культура, музична освіта.

\begin{abstract}
Марквица Войцех
Средства популяризации музыки среди молодежи как важный фактор противодействия «макдональдизации» глобализированной культуры

Популяризацию художественных вкусов как процесс сегодня нельзя рассматривать вне проблем глобализации. Учитывая взгляды современной молодежи на так называемую «классическую музыку», представляется необходимым формировать более высокие эстетические запросы молодого поколения, нежели обеспечиваемые коммерческим развлекательным рынком. Особый вес в этом процессе приобретает художественное образование, в частности музыкальное, не столько воспитание профессиональных музыкантов, как общее музыкальное образование в школе, доступное большинству граждан. Детские школы искусств и музыкальные классы в колледжах искусств должны готовить своих выпускников к дальнейшей учебной деятельности, предоставляя им инструменты формирования общественных художественных вкусов. Не менее важно привить родителям и несущим ответственность взрослым понимание того,
\end{abstract}


что музыкальное искусство чрезвычайно важно для развития ребенка. Такими, казалось бы, простыми, но действенными способами можно сформировать в обществе понимание того, что музыка - это не «элитарное развлечение», а важный элемент формирования индивидуальности и интеллектуальных способностей детей и молодежи.

Ключевые слова: средства популяризации музыки, глобальная культура, музыкальное образование.

(c) Wojciech M. Marchwica, 2017

\section{rom the history of music
education... a few words
of introduction}

Worldwide, especially within the so-called Western culture, there exist now various educational systems of the music teaching. But, over the centuries, professional musicians have been always educating individually within the master-disciple system and profession of musician is treated as special, valuable, and even somewhat mysterious. In many cultures, the music function naturally overlaps with the function of a priest / shaman, and even a prophet, who is able (in his singing) to show the deeper meaning of the signs of the surrounding world.

Even aftertheinstitutionalization of generaleducation, in spite of the emergence of numerous manuals of music execution, singing or theory, the teaching of this art continued to be a subject of individual contact between a teacher and a student. It was not until the second half of the eighteenth century, when music playing became popular among the middle class, that teaching of music should be part of the universal education for those who consider themselves to be "high society". At that time, listening to concerts or opera performances and participation in art gallery events began to be regarded as "well-respected". In the nineteenth century, it was also believed that the participation of young people and children in activities of music ensembles, orchestras and choirs had a positive effect on their intellectual and emotional development, self-discipline and group cohabitation. Music lessons began to appear both in the school programs and during extracurricular activities as well as in kindergartens and summer camps. Today, however, most often it is believed that music education is something extra, is something like filling of leisure time, entertainment rather than any useful occupation. Moreover, music classes are also used as a type of group therapy - a way to improve children in their social activities ${ }^{1}$. Of course, specialized professional art education was still cultivated on the basis of private teaching or art schools created by the famous masters. So famous sculpture and painting studios were working, as well as studios in music conservatories.

${ }^{1}$ Kevin C. Costley The Link Between Musical and Academic Achievement of Young Children Internet publication of 15, January 2011. (The author works at Arkansas Tech University, College of Education, at the pre-school education department).
Western-style music and art understood as a sublime attachment for the middle and upper classes style of life began to narrow their function only to the passive reception of music and art - especially since the Hausmusik (popular especially in Germanspeaking countries) has been losing its popularity even more, the more the cult of God-artist has been growing. Performing of music was more and more reserved for professionals and the ability to play on one of the instruments (mainly on the piano) or singing was perceived as a part of social good manners. "Well-born" and educated maidens simply should - and it was a common believe - be able to play instrumental miniatures or / and sing fashionable arias. Music gradually ceased to be an element of the living culture of salons and became increasingly merely just entertainment. More and more frequent in the program of concerts there were also compositions of the earlier - Baroque and Classical periods, initiating the process of leaving the popularity of the latest works in favor of the most famous ones.

Such a situation prevailed throughout the twentieth century, with a gradual divergence between the latest trends in artistic activity - often rejected by the public for their avant-garde novelty - and so-called basic concert repertoire. In the interwar period and after the Second World War, the professional repertoire of the Philharmonic Orchestra was already based on the classical and romantic concert canon with an addition of "old masters" like: J. S. Bach, G. F. Handel or D. Scarlatti. The result of this transformation was the gradual reduction of the role of music education in general schools. This process was variable in gradation and intensification in various countries. Unlike the situation in Poland, where there was a false conviction about a universal teaching that it should not activate children by playing instruments and singing, in the UK and other Anglo-Saxon countries it has been placed a great emphasis on practicing music for all pupils. The school subject "music" was perceived as very important. The result of this set of circumstances caused the high rank of music teacher in such countries nowadays. For example, at the London Music Education Expo in 2014 (where 125 exhibitor stands were arranged and more than 50 lectures / workshops organized), it appeared not less than 3700 registered participants from all over the United Kingdom. The each $15^{\text {th }}$ of them was a school director. In Poland less than 100 music teachers usually participates in similar fairs, and the quantity of those who held managerial positions is below the limit of statistical error. 
The aforementioned Kevin Costley, summarizing the long-standing debate on the place of music in the education system, states directly "Music should be part of the daily curriculum and integrated throughout many of the subject areas. All students regardless of culture, gender, or race should benefit from the expression and appreciation of music. Music spans the gaps between culture, genders, and prejudice. Music can produce emotion in everyone. The integration of music into the history curriculum allows students to actually feel the mood of that period of time by the feeling that music creates within them." 2 While in Anglo-Saxon culture music education has been and continues to be an important element of general education, in many Central European countries the number of subjects devoted to music and art has been gradually reduced proportionally to the increase of the number of hours devoted to basic and directional subjects. Also the extracurricular activities (choir, ensembles, etc.) are established on the lower and lower levels, reinforcing the belief that music education is an unnecessary ballast, needless for students preparing for intensive job search in the difficult present labor market. At the same time, there is a worldwide growing tendency to treat music as a commercial commodity that serves the public only for inactive consumption, and producers to generate profits. Within this process all: deeper values, cultural identity issues, shaping the aesthetic tastes and intellectual development of man are neglected as irrelevant. ${ }^{3}$

Such an understanding of the role of teaching music in the educational process reflects also in the low position of the music teacher in Polish schools. His role is often neglected, such teachers are treated as almost superfluous. It is observed the paradoxical situation while "music" (although treated as the highly specialized area of education) is often taught by teachers who are not professionally prepared for that role (or gaining appropriate qualifications on the basis of short, substitute courses). On the other hand a large group of MA graduates of the Academies of Music - the direction "musical education" - do not want to work in general schools because they are unable to get approval for their work in the eyes of: pupils, superiors, parents or general public. Remarkably that are American teachers who often criticizes the changes that have been introduced in music education in various countries for years. In an open letter of the International Foundation for Music Research of 1 September 2005, the following comments are made: "In the last decades of the $20^{\text {th }}$ century, music education came under threat and was

2 C. Costley op. cit., p. 8; in his article Costley recalls also opinions from another work by C. Hoffer: Hoffer, C. (1988). Informing Others about Music Education. Music Educator's Journal, Vol. 74 (8), pp. 30-33.

${ }^{3}$ For the discussion of this issue see the brilliant article by M. Breen The End of the World as We Know it: Popular Music's Cultural Mobility. Cultural Studies, Vol. 9, Issue 3, 01.10.1995, pp. 486-504. marginalized in the school curriculum. This threat was realized in the elimination of thousands of programs and substantial cutbacks of qualified and certified music educators. It is believed that music education is a subject with intrinsic cultural and artistic value and a skill-based activity that nurtures developmental and cognitive aspects of every child. However, only recently have the benefits of active participation in music been quantified through scientific research." 4

Only in some countries, where music culture is treated as part of the protected national heritage, the conditions are slightly different. This situation could be exemplified in Kazakhstan, where "народная музыка" [national music] is one of the elements of the government's consistent cultural policy aimed at merging the Kazakh nation (derived from diverse ethnic groups and numerous independent clans). The basis of music teaching is conducted there based on playing the folk instruments like dombra or kobyz. Children - instead of learning solmization or European music score system - start by recognizing the basic intervals played on the instrument and extracted from the popular native songs. This method has been successfully applied in many schools for about last 20 years, and the ultimate goal is to preserve the national style of Kazakh music, which is largely based on improvisation techniques. ${ }^{5}$ The repertoire performed during school shows is based on traditional Kazakh music or on contemporary compositions created for traditional instruments.
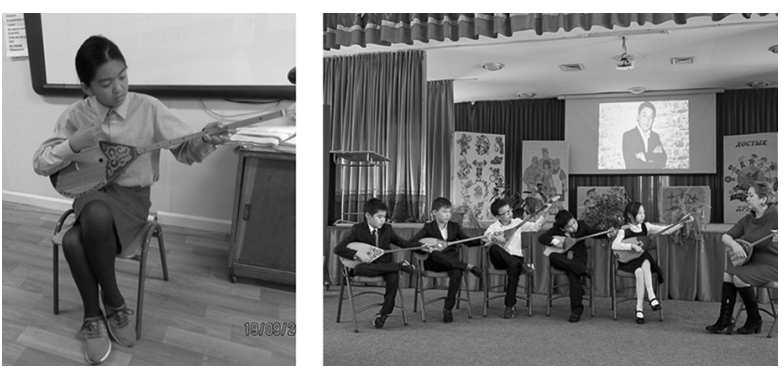

Fig. 1. Teaching of dombra playing in general Kazakh school ${ }^{6}$ (http://tamos-education.kz/wp-content/uploads/2015/12/dombra-1.jpg)

4 Sounds of Learning The Impact of Music Education Open Letter from Mary Luerhsen, International Foundation for Music Research and Soloproject;

https://www.nammfoundation.org/sites/default/files/ Sounds $\% 20$ of $\% 20$ Learning_The $\% 20$ Impact $\% 20$ of $\% 20$ Music\%20Education.pdf

5 See for example the paper delivered during the conference hold in 2009 in Indiana University: G. T. Alpesova. Music Education Problems of Traditional Musicians in Kazakhstan at the Turn of the $21^{\text {st }}$ Century The Sixteenth Annual Central Eurassian Studies Conference. Indiana University, USA, 2009; p. 17.

6 Such a concerts are quite frequent in general schools in Kazakhstan - see the example of Math-Physic school in Almaty (Частная Физико-Математическая Школа Тамос Эдьюкейшн, Almaty, Kazachstan; http://tamos-education. kz/muzykalno-horeo/ seen 19.03.2017). One can easily find the numerous teaching materials suitable for this topic like: https://www.o-detstve.ru/forteachers/kindergarten/artesthetic-development/16159.html seen 19.03.2017. 
The classic Western European music repertoire for groups of traditional instruments is also popular. This type of approach increases the attractiveness of the subject "music" and at the same time emphasizes the uniqueness of one's own cultural traditions.

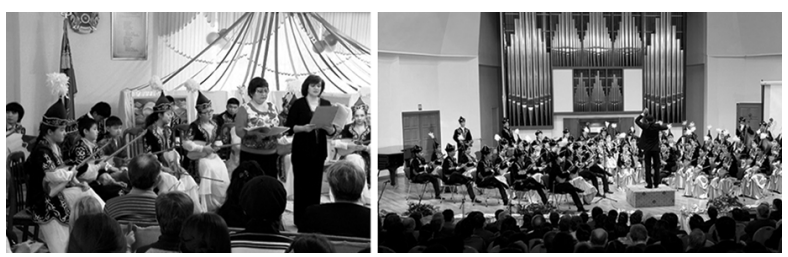

Fig. 2

Two bands composed of traditional instruments during

the performance: the general school in Satpaev

(the Karaganda circuit http://azbyka.kz/muzyka-kompozitorov-

kazahstana-v-repertuare-yunyh-muzykantov)

Orchestra of the National Musical Conservatory named after

Kurmangazy in Almaty

(http://m.inform.kz/en/article/2902717)

Similar problems exist in numerous postSoviet countries, but the effects of cultural policy are different. For example, in Mongolia, focusing on the process of nationalization, commercialization and popularization of musical culture has led to its politicization similar to that of the previous era. Musical culture in post-communist Mongolia can be considered as a continuation, transformation and, in some cases, even an intensification of the process of building a state culture, aimed at the "national socialist form of content". It shows the approach to "national" or "folk" music in the process of building modern state culture can lead to undesirable effects. ${ }^{7}$ It seems that although the models of universal music education in different countries can and should vary considerably, it is necessary to broadly introduce music education - due to raise the general intellectual level of whole society.

Although half a century ago it seemed that the cultural diversity of individual countries was something inevitable, obvious, and naturally included in the multicultural picture of our planet, however, the rapid development of the mass media, the facilitation of travel, and the political processes leading to closer international cooperation led to the realization of the vision of a global village created by Marshall McLuhan's. Pop rock in the 60's and pop music in the decades following not only reduced the aesthetic level of the average recipient but led us all to the overwhelming but fearsome phenomenon of passive music consumption. In the face of a flood of cheap and simple portable

7 Tsetsentsolmon, B. (2015). Music in Cultural Construction: Nationalisation, Popularisation and Commercialisation of Mongolian Music. "Inner Asia" Vol. 17, Issue 1, 21.04.2015, pp. 118-140. music players (from popular cassettes, Walkman's to modern MP3 players), the masses began to listen to music without seeing or needing to participate in music performances or attending concerts aside from star-tours or popular festivals. This occurrence has been compounded by the easy dissemination of recordings by leading soloists and bands heavily advertised by phonographic companies. Globalization and the McDonaldization of popular culture since the 1960s is a fact based not only on progression of passive consumption of music or aversion to local and national traditions. The consistent rejection of so-called Classical music is being accompanied by the word fashion for importing American culture (the very good example is Japan or South Korea) and the expansion of rock, jazz and pop music. Therefor in the last decades of the $20^{\text {th }}$ century, music education came under threat and was marginalized in the school curricula.

An excellent analytical study of this phenomenon is an article published in 2011 A Cultural Globalization of Popular Music? ${ }^{8}$ The authors stress that since the 1960's there has been a gradual domination or hegemonization of world music culture mainly through American music. As they call the sequence of the whole process one can talks - in some cases - about a global tastes change by adapting American patterns to local styles and tastes (glocalization). Over a piece of time, however, various local styles and genres have started to be globally reproduced and adapted - what may be called multiculturalization. An example of this development is the world-wide career of didgeridoo - the instrument known yet fifty years ago only in Australia. This career is really astonishing starting on the first attempts to use this instrument at the turn of the ' 70 s and ' 80 s by Kate Bush $^{9}$, by popularizing the instrument in the 1980s by the Yothu Yindi team, up to Djalu Guruwiwi and other $21^{\text {st }}$ century artists.

Analyzes of the lists of hits of 1965-2006 quoted in the aforementioned article A Cultural Globalization of Popular Music? concern the USA, Germany, the Netherlands and France and clearly show the dominance of American musicians and music by the end of the $20^{\text {th }}$ century. The dominant language of pop music is English (in Germany

8 Peter Achterberg, Johan Heilbron, Dick Houtman, and Stef Aupers A Cultural Globalization of Popular Music? American, Dutch, French, and German Popular Music Charts (1965 to 2006) American Behavioral Scientist 55(5) 589-608; http:// journals.sagepub.com/doi/pdf/10.1177/0002764211398081, seen 24.03.2017, DOI: 10.1177/0002764211398081.

9 It is starting with her first album The Kick Inside (Kate Bush, The Kick Inside [CD-ROM], EMI 1978, ISBN 077774601221ROM), and particularly her fourth album of 1982 Dreaming (Kate Bush, The Dreaming [CD-ROM], EMI 1982, ISBN 077774636124). 
71.0 \%, in Holland 78.1 \%, even in France it is $57.1 \%$ ). The predominance of international artists' music and the hegemony of American culture are also evident. However, since the beginning of the century there has been a slight change in the trend, and the role of local artists who gain international recognition is growing gently. It can therefore be said that American hegemonization is slowly transforming itself into multicultural globalization. It does not however change the fact that classical music a carrier of higher aesthetic values - is consistently displaced by different genres and subspecies of mainstream (pop, rock, or jazz) and, increasingly, niche subgroups that benefit from the opportunities offered by the Internet.

The problem we face at the beginning of the $21^{\text {st }}$ century is the incompatibility of the techniques and content of learning music to a changing world. Within the system of artistic education there is still a domination of the teaching of the so-called classical music, despite the reception are dominated by various genres of pop music, jazz and other entertainment. This proves even a disproportion in the interest of Grammy winners. In the year 2016, the 84 categories for this prestigious award only 9 (in the list at the end of the list, items 74-82) concerned classical music!

Similar conclusions are drawn by the analysis of statistics on the sale of music of different genres. According to the website of the statistical distribution Statista the sale of music albums broken down into specific music types looks as follows:

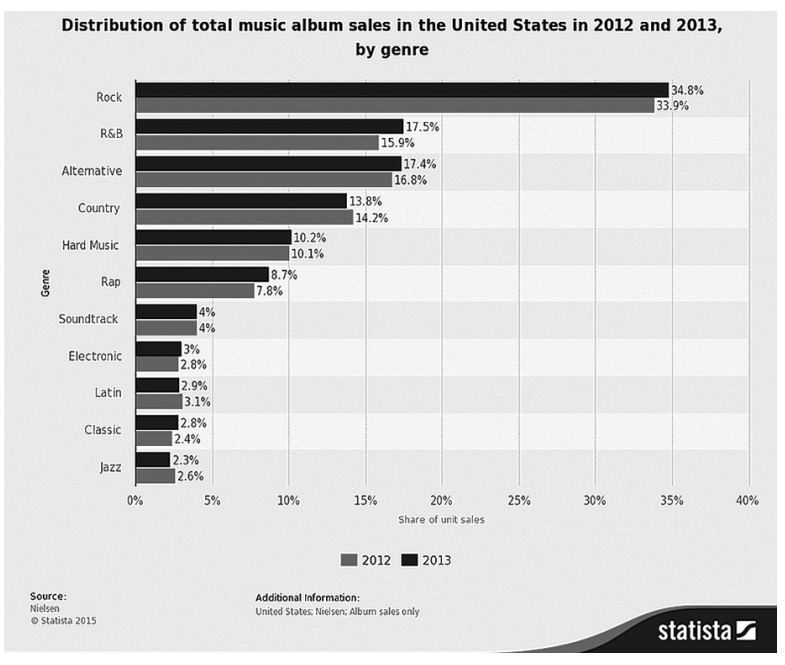

Fig. 3. US album sales statistics for 2012-2013

Source portal Statista (https://www.statista.com/statistics/310746/ share-music-album-sales-us-genre/ seen 25.03.2017)

As one can see, the share of classical music sales in the period under review has not reached $3 \%$. Even worse is, that in the years 2008-2012 in the US issued more than 10 million albums of classical music on average a year, but this number has gradually decreased from 13.32 million in 2008 to 7.5 million in 2012. ${ }^{10}$ Similar Australian data from 2005 to 2016 range between $3.2 \%$ and $5.8 \%$ (average $4.3 \%$ ) of classical and opera music in the music market. ${ }^{11}$ Even when we consider only an interest in a particular genre of music (the respondent might indicate a few) the "classical" music in the US with a score of $15 \%$ was scarcely ranked No. 7:

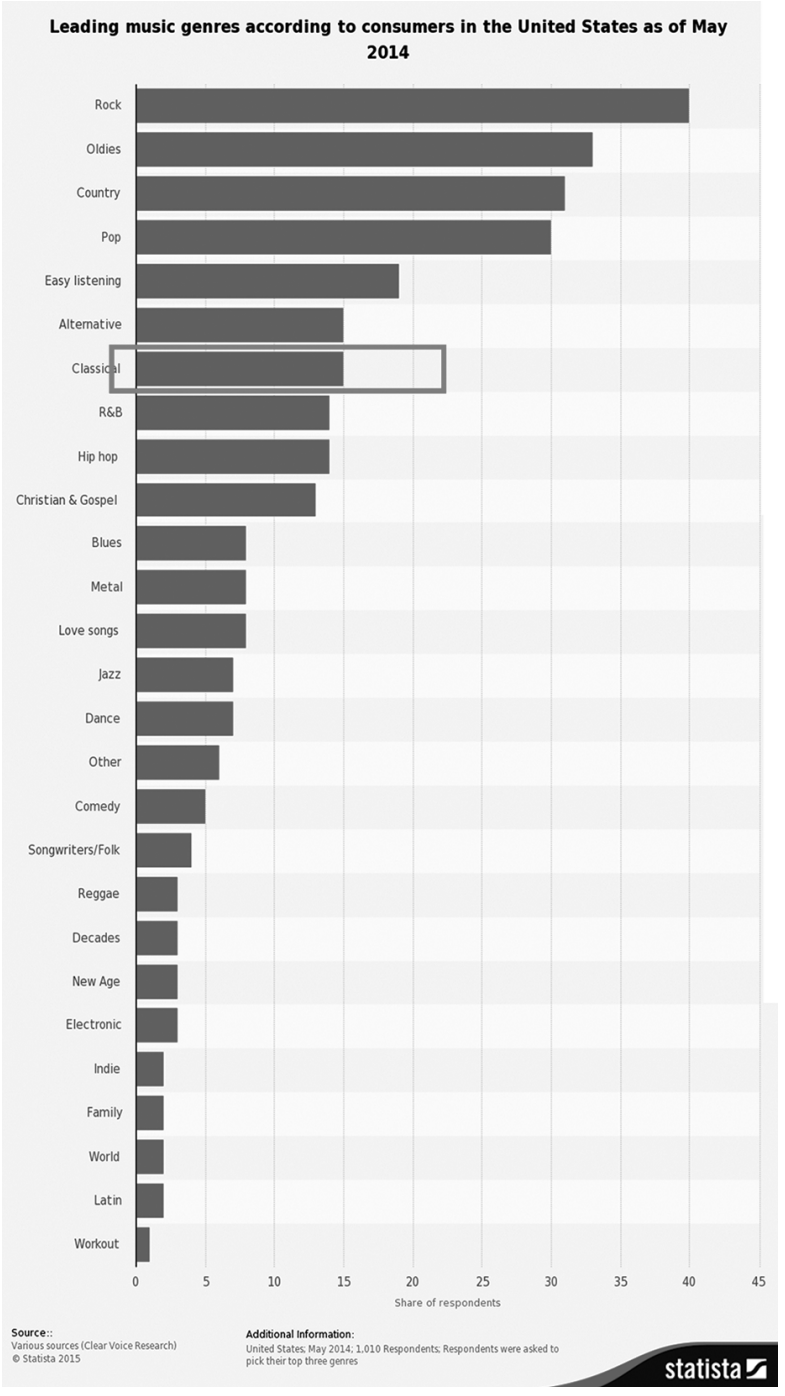

Fig. 4. Research Statista GmbH from 2014 -

favorite music genres in the USA

(https://www.statista.com/statistics/442354/music-genres-preferred-

consumers-usa/ seen 25.03.2017)

Not to be confined solely to Anglo-Saxon culture, it will be interesting to look at the Japanese market for comparison (see the illustration 5 below). The distribution of preferences of customers does

10 The research available on the website of company registered in Hamburg Statista GmbH

https://www.statista.com/statistics/188910/us-musicalbum-sales-by-genre-2010/, seen 22.03.2017.

11 Research conducted by Australian Recording Industry Association Ltd. Sales by Region and Genre for the Years Ended 31 December 2006-2015

http://www.aria.com.au/pages/statistics.htm, seen 22.03.2017. 
not differ there from data from other Western countries. However the number of music albums sold within a particular genre (including the distribution of "native" and "international" music) shows that 129 "domestic" Japanese classical music albums account for less than $1 \%$ of the total number of albums produced in Japan (out of 15712 overall) but albums with an international repertoire account for as much as $11 \%$ of production. This statement can be used to demonstrate the influence to the taste of consumers through the overproduction of classical music ( $12 \%$ in total) compared to other genres. The chart does not include imports from abroad, which in the case of classical music can be significant.

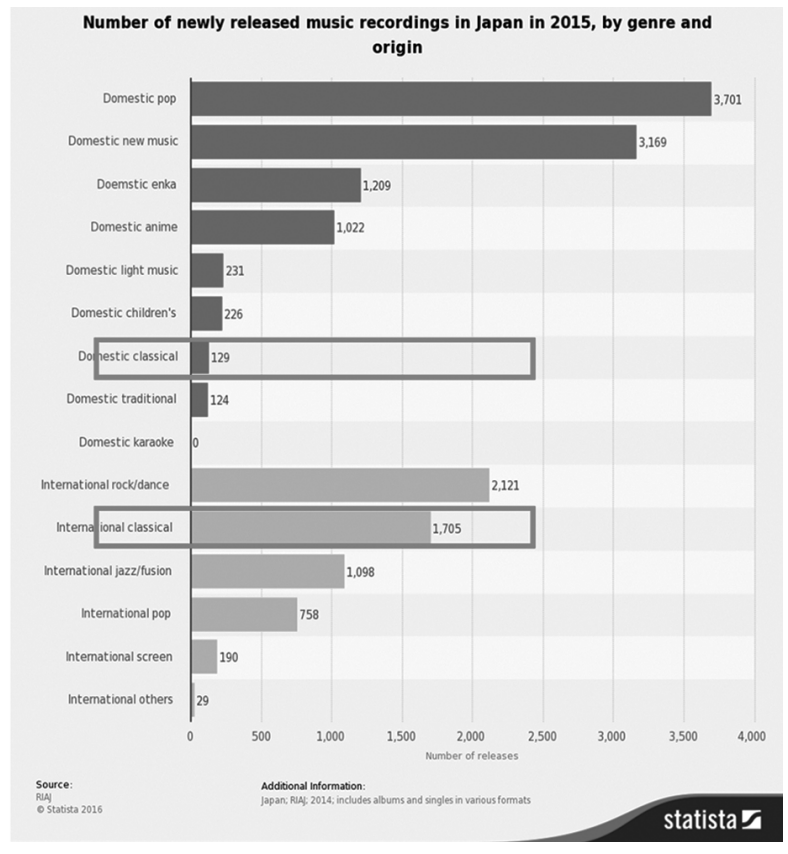

Fig. 5. Badania Statista GmbH z roku 2015 -

nagrania muzyczne w wartościach bezwzględnych

(https://www.statista.com/statistics/521858/number-new-music-

release-recording-japan/dostęp 25.03.201)

Remembering how music education is taking place both in the professional education sector and in general education, it is easy to understand the complete lack of credibility of the current educational system in the world music market. For several decades, however, they can be observed changes in this area.

\section{The music teaching - gradual changes}

Changes in the music education system do not keep pace with these dynamic changes in the global music market. Although the vast majority of citizens in developed countries use commonly music players, the widespread education of musical tastes or deepened reflection on music is only a tiny fraction of the time dedicated to the education of children, adolescents and adults. It is still prevailing that music education is something additional, separate from "basic" education, it is more fun than a useful activity.

Meanwhile, mainly Anglo-Saxon methodologists emphasize that music should not only be an obligatory part of the daily curriculum, but should be included in the various school subjects. It is also often noted that music (like speech) is an inherent part of humanity and is found in all cultures known to us. ${ }^{12}$ Although music is not - as it was commonly thought - a universal language, intercultural research confirms that music itself is universal. In various works, ${ }^{13}$ it is confirmed that active music performance in childhood (contrary to passive listening) significantly affects the development of the brain. Neurologist Frank Wilson demonstrates that we all have a biological guarantee of musicality. ${ }^{14}$ Therefore, access to music should not be limited to those "talented" or only to those whose parents can afford music education for their children. Nori Jacoby and Merav Ahissar argue directly: "Most people who study music do so for pleasure rather than as a means for attaining other skills, just as is the case for avid players of action video games. Yet, expert musicians were reported to have enhanced verbal and phonological skills and higher intelligence. Although these may reflect a selection bias for people playing music, an exciting hypothesis is that their musical education contributed to their linguistic skills or intelligence." 15

Private education - both general and professional, involved in the professional training of musicians has reacted swiftly to a global cultural change. In private schools it is often more likely the subject "music" is taught on a better level and to a larger extent than in public schools. There has also been a growing segment of artistic education - from spontaneous jazz and rock courses to extreme-school specialties a good example is a world-class career in Speech Level Singing schools promoted by Seth Riggs and his method. ${ }^{16}$ Following these changes public schools are progressively strengthening the education segment of musicians specializing in non-classical music: jazz, pop, rock, musical, etc. and supporting amateur music other than school orchestras or choirs.

12 See C. Hoffer, C. (1988) op. cit. pp. 30-33.

13 Among others: Lawrence Parsons, Peter Fox, and Donald Hodges Neural Basis of the Comprehension of Musical Melody, Harmony, and Rhythm the article presented during the conference of Society for Neuroscience, Los Angeles, November 1998.

14 "all of us have a biologic guarantee of musicianship" Frank Wilson, Tone Deaf and All Thumbs? New York: Viking, 1986, p. 2.

${ }_{15}$ N.Jacoby, Merav Ahissar What does It take to Show that a Cognitive Training Procedure is Useful? A Critical Evaluation „Progress in Brain Research”, Vol. 207, p. 132; ISSN 0079-6123, http://dx.doi.org/10.1016/B978-0-444-63327-9.00004-7, seen 21.04.2015.

16 Seth Riggs Vocal Studio; see: Seth Riggs, Singing for the Stars, Alfred Music, 1992. 
A number of associations, foundations and other NGOs (working on lifelong learning and shaping the audience's taste) also play an increasingly important role by:

- sensitization of children (from the very early ages 1-3) to music and art through practical classes,

- raising the level of artistic education in general education - accustoming children and young people to phenomena aesthetically good by supporting musical amateur movements,

- constant awareness of the role of music education in the education process - in line with the results of psychological and cognitive sciences,

- raising the level of the subject "music" in common schools,

- using local learning experiences in the education of children and youth,

- professional art criticism - especially on the Internet and social media,

- professional enrichment of events for the general public through interesting artistic initiatives during open lectures and presentations, open air festivals, concerts with commentaries, etc.,

- generally encourage active engagement with art - and not only through passive consumption of music and art.

The above-mentioned methods of action are fully compatible with the scientifically proven influence of music on the intellectual and emotional development of man. In the aforementioned Sounds of Learning project (see footnote 4 above) Donald A. Hodges and Debra S. O'Connell discuss this issue in greater depth. The question of the impact of music education on academic achievement is answered affirmatively in research conducted since the 1990s and in the analysis of statistics. For example, S. J. Morrison, ${ }^{17}$ analyzing data from the American National Center for Educational Statistics, on a sample of 13327 students and secondary school graduates found that those who participated in music education had higher marks in English, mathematics, history and science than those who did not. Numerous further attempts obtained on the basis of various knowledge tests used in the USA have been made to evaluate these results. The results were confirmed despite the different age of students and geographical areas of the samples. The conclusions of this work come down to the following findings:

- It is generally acknowledged that those who participated in music classes (both music knowledge, practice in singing / singing and

17 Morrison, S.J. (1994). Music Students and Academic Growth. Music Educators Journal, 81 (2), pp. 33-36. participation in music ensembles) achieved better results in college. ${ }^{18}$

- Comparing music-educated people with sportspeople and those who did not attend extra classes, "musicians" were better performing than "athletes"; a comparison group had ratings similar to "musicians", but their ratings were less stable (larger standard deviation of the tests). ${ }^{19}$

- Detailed research of achievements for those who have participated in music education for a minimum of 6 years have shown that their mean scores were significantly higher - especially in language, arts and mathematics. ${ }^{20}$

- Among pre-school children, there is a strong correlation between the ability to read and recognize sounds, one of the major measures of musicality in children.21

- Detailed studies also show that music educated people before the age of 12 have significantly better verbal (though not visual) memory. ${ }^{22}$

- In the US - like in Poland - at the turn of the $20^{\text {th }}$ and $21^{\text {st }}$ centuries test results in mathematics do not show significant progress. The results at the lower secondary level show little improvement, but the tests at the secondary level since 1996 remain unchanged. However, there are conclusive results of experiments showing that the correlation between music education and the results of "mathematical" tests is statistically significant in all examined areas (arithmetic, logic, combinatorics). ${ }^{23}$

18 Cardarelli, D.M. (2003). The Effects of Music Instrumental Training on Performance on the Reading and Mathematics Portions of the Florida Comprehensive Achievement Test for Third-grade Students, $\mathrm{PhD}$ dissertation University of Central Florida "Dissertation Abstracts International", 64 (10), p. 3624A.

19 Schneider, T.W., Klotz, J. (2000). The Impact of Music Education and Athletic Participation on Academic Achievement ERIC Document Reproduction Service No. ED448186.

20 Palos-Tuley, B. (2003). An Examination of the Relationship Between Fine Arts Experiences and Creative Thinking, Academic Self-concept, and Academic Achievement of Hispanic Students in Grades 3, 4, and 5 in Selected South Texas Schools, $\mathrm{PhD}$ dissertation, Texas A \& M University, Dissertation Abstracts International, 65 (01), p. 008A.

21 Lamb, S.J., Gregory, A.H. (1993). The Relationship between Music and Reading in Beginning Readers. Educational Psychology: An International Journal of Experimental Educational Psychology, 13 (1), pp. 19-27.

${ }^{22}$ Chan, A.S., Ho, Y.C., Cheung, M.C. (1998). Music Training Improves Verbal Memory. Nature, 396, pp. 128-129; Ho, Y.C., Cheung, M.C., Chan , A.S. (2003.) Music Training Improves Verbal but not Visual Memory Cross-Sectional and Longitudinal Explorations in Children, Neuropsychology, 17 (3), pp. 439-450.

23 Vaughn, K. (2000). Music and Mathematics: Modest Support for the Oft-Claimed Relationship, Journal of Aesthetic Education, 34 (3-4), pp. 149-166. 
The above-mentioned and returning as a leitmotive topic of the relationship between music skills and the ability to study science was also comprehensively analyzed. Carlos Santos-Luiz in a 2007 article The Learning of Music as a Means to Improve Mathematical Skills ${ }^{24}$ admits that music refers to mathematics in different areas. Apart from the obvious synergy within the acoustics (the sphere of physical definition of music, the issues of pitch, intervals, aliquots, etc.) the foundations of rhythm and melody can also be defined mathematically, by means of metrics, proportions, symmetry - analogous to mathematical activities such as division, multiplication or logarithmic functions. Mathematical formulas were also used directly in the compositions of many artists from W. Byrd through J.S. Bach to O. Messiaen. The mathematical expressions of the Fibonacci sequence or the "golden ratio" were also the formal basis of numerous musical works (including those of B. Bartók, W. Lutosławski and others). In addition, there are such models of reception psychology, where, in relation to the connection between music and spatial imagination, performance of the melody is reduced to reconstructing the spacetime pattern. In this formula, elements are not twodimensional jigsaw puzzles but notes of different heights and duration. This is why so many studies and tests emphasize the high correlation between musical talent and the ability to precisely abstract or spatial thinking. These conclusions are confirmed by recent discoveries by neurophysiologists who find that structurally neuronal cortex (developed by X. Leng and G. L. Shaw ${ }^{25}$ ) called the "trion model" confirms the neuroscientific context of the relatioeship between music and spatial imagination.

The research of this type is still continuing and confirms ever more precisely the earlier findings. In the article from 2013 Long-Term Musical Training may Improve Different Forms of Visual Attention Ability ${ }^{26}$ the authors found that musicians have reached an advantage over the non-musicians in perceptual tests. In addition, there was a significant positive correlation among musicians between the age of start the music studies and the reaction time in all perceptual studies. The results suggest that musicians present augmented ability in different forms of visual attention, thus illustrating the possible cognitive benefits of long-term musical training. Research published

24 Santos-Luiz, C. The Learning of Music as a Means to Improve Mathematical Skills [w]. Proceedings of the International Symposium on Performance Science 2007 ed. Aaron Williamon AEC 2007, ISBN 978-90-9022484-8, pp. 135-140.

25 Leng, X., Shaw, G.L. (1991). Toward a Neural Theory of Higher Brain Function Using Music as a Window. Concepts in Neuroscience, 2, pp. 229-258.

26 Rodrigues, A.C., Loureiro, M.A., Caramelli P. (2013). Long-Term Musical Training may Improve Different Forms of Visualattention Ability. Brain and Cognition, 82, pp. 229-235. a year later not only confirmed structural brain modifications in the auditory, motor and visuospatial areas of musicians compared with non-musicians. A group of scholars, under the leadership of Mathilde Groussard, ${ }^{27}$ published the results of their experiments based on a study of 44 young people (up to 26 years old), that music training increases the amount of grey cells in different areas of the brain in the music subgroup. Changes have gradually appeared in different areas starting with the hippocampus. These experimental findings confirm the view that music training can cause dynamic structural changes in the brain.

Cognitive science seems to be particularly promising, because it not only confirms the importance of dealing with music as a general intellectual exercise that develops human intelligence, but also with lower cognitive abilities such as flexibility in thinking, problem solving ability, verbal ability, or spatial thinking. A good introduction to the subject is the article of great authority in this field, Donald A. Hodges. ${ }^{28}$ The research team led by P.J. Silvia established - with the method of bifactor modeling - that music training has both general and specific correlations with the mental development of the examined people. ${ }^{29}$ Their findings confirm previous research into the appropriateness of the wide use of training methods that use music and identify the importance of association with music for cognitive development.

Out of the opinions presented above, it appears a clear need to create and facilitate long-term contact with music not for pleasure or entertainment, but primarily for the stimulation of intellectual and emotional development of man. At every recall opinion it is emphasized that the most important is the systematic mode of music education, the practical training of various forms of musical activity and the long-term impact of music, going beyond the period of general education. The demands of psychologists and cognitivists come down to professional support for events for the general public ranging from a school age up to the "third age". It is necessary to take interesting artistic initiatives, create and popularize the free for a wide audience: lectures, presentations, outdoor fairs, concerts with commentaries, etc. Contrary

27 Groussard, M., Viader, F., Landeau, B., Desgranges, B., Eustache, F., Platel H. (2014). The Effects of Musical Practice on Structural Plasticity: The Dynamics of Grey Matter Changes. Brain and Cognition, 90 (2014), pp. 174-180.

28 Donald, A. Hodges. (Sep., 2000). Implications of Music and Brain Research. Music Educators Journal, Vol. 87, No. 2, Special Focus: Music and the Brain, pp. 17-22; http://www.jstor.org/stable/3399643 seen 01.04.2014.

29 Silvia, P.J., Thomas, K.S., Nusbaum, E.C., Beaty, R.E., Hodges, D.A. How Does Music Training Predict Cognitive Abilities? A Bifactor Approach to Musical Expertise and Intelligence. Psychology of Aesthetics, Creativity, and the Arts, Vol. 10, Issue 2, 01.05.2016, pp. 184-190; DOI: 10.1037/ aca0000058. 
to the trend described in the introductory chapter, it is also necessary to encourage the public to actively engage with the arts and music - and not merely consent to a passive consumption of music. In the age of the Internet, the importance of professional art criticism is also of particular importance - especially in social media. Too often today, people defining the aesthetic judgments and shaping the public opinion are casual bloggers, whose main strength is delight over their own judgments. As the Internet becomes more and more "free in its opinions", it is possible and desirable to further and popularize such attitudes, which aim to deepen the knowledge of music and promote aesthetically mature views.

\section{Past experience - good practices}

In many cultural centers around the world the role of lifelong learning — shaping tastes — is gradually increasing through a number of initiatives such as: open lectures and presentations in museums, open days or concert-lectures prepared for different age groups. The activities of institutions such as the Vienna Haus der Musik, the Parisian Cité de la musique and some British orchestras are excellent examples to follow. Equally important are the initiatives of smaller organizations - mainly NGOs. Let's look closer at some of such good practices.

One of such ideas is the project, conducted in recent years in the UK, Sounds of Intent in the Early Years (SoI-EY), which examines the impact of music on children from ten-week-olds to "adult" fiveyear-olds. ${ }^{30}$ There were realized 125 observations of 58 children who participated in special music lessons in the form of video recordings. The study was conducted for 6 months. All observations were analyzed using originally design for Sounds of Intent in the Early Years' rules to determine if and how types and levels of music interaction could be described in an existing model. This allowed researchers to identify both areas of potential mismatch and reinforcement. It has been proven that musical development was a multidimensional process, that children responded well to sound, were able to create and control sound well, and collaborate with the group during the creation of a musical act. These observations allowed to construct the precise diagrams describing the behavior of children and facilitating their preparation for participation in the production and reception of music.

Another interesting project is JeKi. Valerie KruppSchleußner and Andreas Lehmann-Wermser have examined $^{31}$ how the German Instrument for Every

30 Voyajolu, A., Ockelford A. (2016). Sounds of Intent in the Early Years: A Proposed Framework of Young Children's Musical Development. Research Studies in Music Education, Vol. 38 (1) pp. 93-113.

31 V. Krupp-Schleußner, V., Lehmann-Wermser A. (2016). An instrument for Every Child: a Study on Long-Term
Child (JeKi) program, which tends to teach the instrument at elementary school, affects the musical sensitivity of young teens in grades 6 and 7. The results unambiguously indicate that children's affinity for music (e.g. related to a particular genre or its popularity in an age group) and attitudes to music brought from home have the greatest impact on the motivation of learning the instrument. Based on these and other works many other practical projects have been proposed and realized. A Polish one is Smykofonia [smyk = affectionately "little child"; Fonia $=$ phonos $=$ "sound"] prepared and conducted in Poland in many cities by the Association of Music Teachers [Stowarzyszenie Nauczycieli Muzyki]. The project involves sensitizing children (from early childhood 1-3 years) to music and art through hands-on activities. This series of concerts / workshops activating the youngest children assumes participation in the activities of their carers. It is interesting that professional musicians who conduct such classes often feel satisfaction comparable to philharmonic performances. They emphasize that the emotional involvement of children and their desire to get to know the instrument, the technique of the play, the meaning of the presented music outstrips the involvement of typical music lovers.
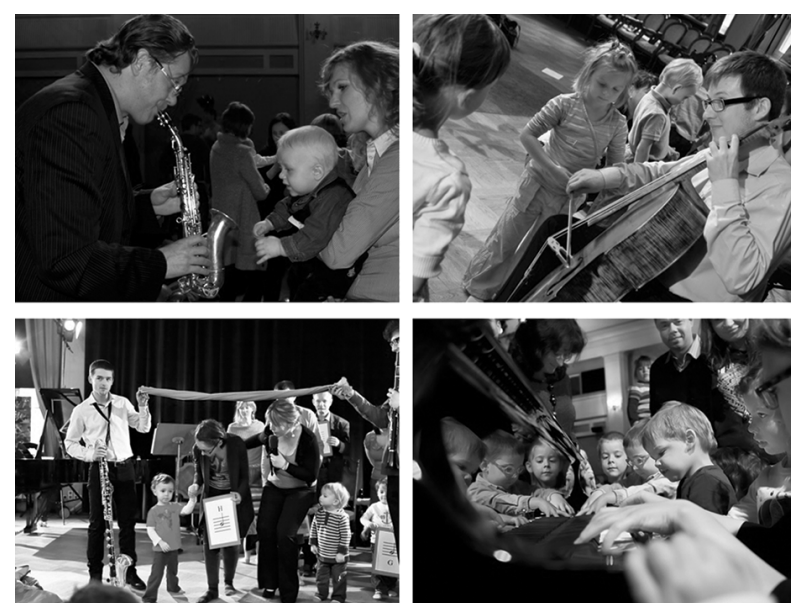

Fig. 6. Documentation of one of the Smykofonia concerts (14.05.2015) (C) SNM Archive

The Anglo-Saxon system, which attaches great importance to music in general schools through participation in music ensembles, orchestras, choirs, etc. is of course a worthwhile model to follow. In many countries such "raising the level of music education" may be unrealistic, but the activity of passionate teachers and tutors of extracurricular activities can do wonders. Important here is the role of methodologists and coaches - responsible for the implementation of the relevant provisions of the curriculum and

Effects of Extended Music Education in German Primary Schools. Music Education Research, Published online: 03.11.2016; DOI: 10.1080/14613808.2016.1249361;

http://dx.doi.org/10.1080/14613808.2016.1249361. 
regulations into national education systems. In Poland, for example, unfortunately, it has long been mistakenly assumed that in general education children should not be activated by playing on instruments. Such musical training was reserved for teaching in art schools only. One of thousands of positive examples to follow can be the orchestra at Carslbad High School, a public school in California (USA) that prepares professional concerts with amateur musicians.
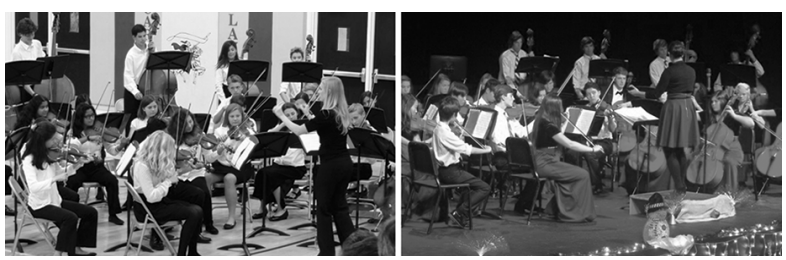

Fig. 7

CHS Orchestra, Carlsbad CA, USA, winter concert (17.12.2014)

Yearly Gala Concert (26.03.2015)

(http://carlsbadorchestra.weebly.com/photos; seen 27.03.2017)

Another good example to follow may be already mentioned - Kazakh patterns. It is not just about a unique system of teaching music with the use of folk instruments. Such instruments as dombra or kobyz in the local school system are starting point for teaching music theory, music practice, national history and other general topics such as patriotism. For younger children playing dombra and listening the story of this instrument is also entering the mysterious world of fairy tales. The Legend of the Golden Dombra published in the lesson outline ${ }^{32}$ acts as a key to many lands and a canvas for the study of national culture.
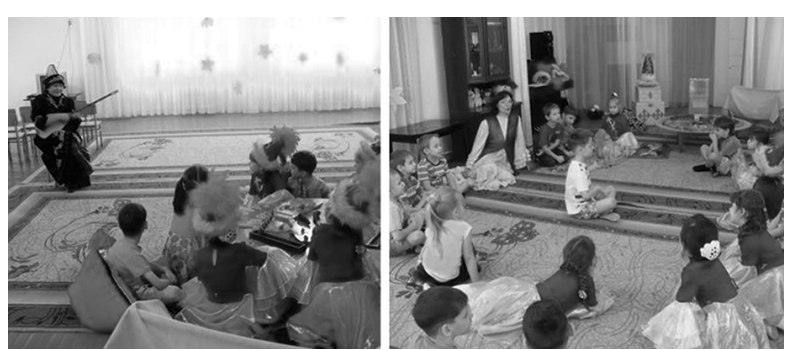

Fig. 8. Photos of the class based on Legend of the Golden Dombra (https://www.o-detstve.ru/forteachers/kindergarten/art-estheticdevelopment/16159.html; seen 21.03.2015)

It is necessary to prepare professional teachers, critics and popularizers to implement widely activities described above. Many universities understand such necessity and therefore organize a variety of academic

32 See for example the class syllabus based on the Legend of the Golden Dombra [Автор: Сусленкова Лариса Владимировна, музыкальный руководитель 1 квалификационной категории ясли-сада №8 «Теремок», город Экибастуз Павлодарской области, Республика Казахстан. Педагогический стаж 28 лет];

https://www.o-detstve.ru/forteachers/kindergarten/artesthetic-development/16159.html seen 25.03.2017. courses to solve this issue. ${ }^{33}$ In my Institute of Musicology (Jagiellonian University) the classes of "popularizing music" (D332), "music criticism" (F667) and "journalistic rhetoric" (D330) are very popular. Such courses require from students to deep and link their knowledge of the various disciplines to meet the demands of a highly diversified music popularization market.

Among the many other perfect initiatives appear the activities of the Polish Fryderyk Chopin Institute (NIFC) addressed to different groups and realized in various forms. The NIFC education department prepares a great deal of lectures or presentations for adults (mainly pensioners) who do not afraid to participate in the discussions on often complex issues. Such meetings were the IQ Chopin cycle devoted to the in-depth analysis of the Chopin documentation, the discussion of George Sand's book, Lucrezia Floriani, and the issues of analysis and interpretation of music works. A special cycle is the Historic Songs - activating workshops for seniors - consisting in the joint performance of historical songs from the turn of the $18^{\text {th }}$ and $19^{\text {th }}$ centuries.
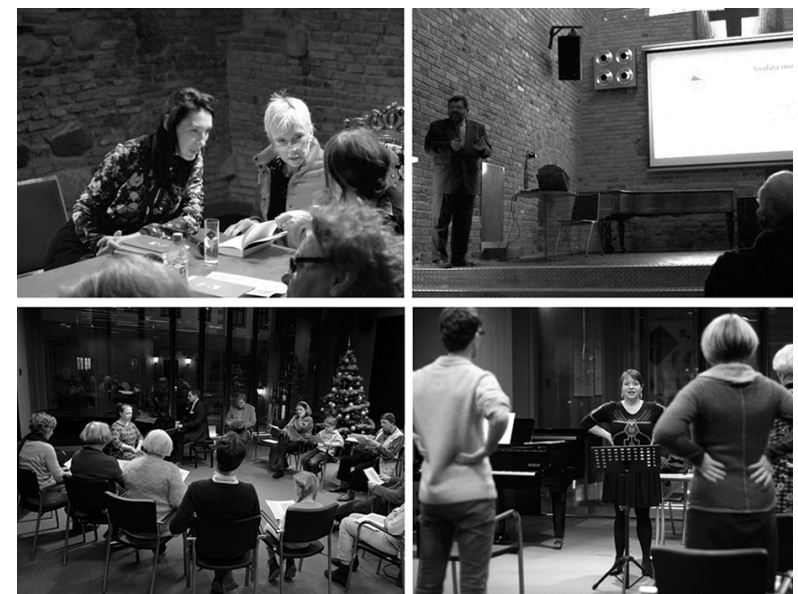

Fig. 9

Meeting IQ Chopin. Lucrezia Floriani with participation of famous actress Ewa Błaszczyk (08.04.2014)

Music Analysis - What For? Wojciech Marchwica (27.02.2015)

Workshops Historic Songs [Śpiewy historyczne] (18.01.2017)

(C) NIFC Archive

Workshops of artistic activation for children conducted under the name of Little Chopin Academy are also prized by many years of tradition.

${ }^{33}$ For example: Music Academy in Krakow Postgraduate Studies - Music Criticism [Akademia Muzyczna w Krakowie Studia podyplomowe - Krytyka muzyczna]; the similar area is covered by various courses of $\mathrm{Ba}, \mathrm{Ma}$ and $\mathrm{PhD}$ level in Warsaw, Poznań and Krakow; in other countries: MUS 121 - Writing about Music in Queens College, NY USA; Writing About Popular Music in Gallatin School - New York University; Rhetorical Approaches to Popular Music USC, CA USA; Music Criticism Course at the Department of Music Tallinn University, Estonia; Music Criticism in Practice University of Glasgow, UK. 

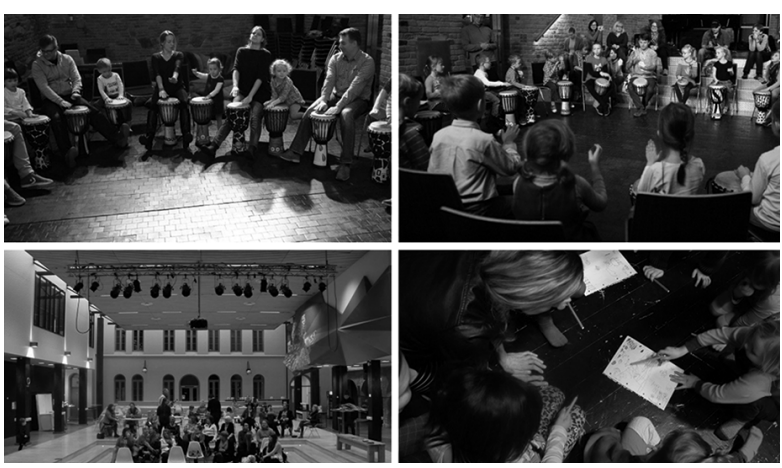

Fig. 10. Workshops for children:

Little Chopin Academy (05.11.2015)

Workshop in Fridrikstadt, Norway (14.01.2013)

(photo by Katarzyna Kasica) (c) NIFC Archive

Children between the ages of 5 and 15 participate in art workshops inspired by music, animation games, and listen to short performances. The measure of the success of thematic education cycles is the desire to visit the Academy by the same groups in subsequent years. Undoubtedly the most awaited projects for children at NIFC are outdoor events where the slogan "learning through fun" is realized in dozens of ways. In the beautiful scenery of the park in Żelazowa Wola are organized numerous music, sculpture, painting workshops, and on the stage they are live performances by professional artists and children from the music school in Sochaczew. Individual positions are dedicated to different age groups and throughout the park is realized field game of musical history.

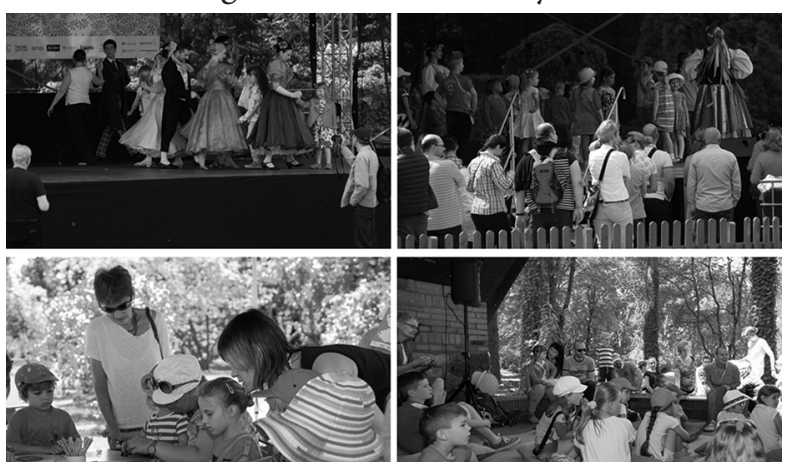

Fig. 11

Children's Day - Żelazowa Wola - above workshops of historical and folk dance (02.06.2015, photo by Anna Kierkosz) Workshop (05.06.2016, photo by Waldemar Kielichowski) (C) NIFC Archive
Fryderyk Chopin Institute attaches great importance to music workshops. Percussion workshops always enjoy great success. Not less the fun-loving music games are prepared by the animators.
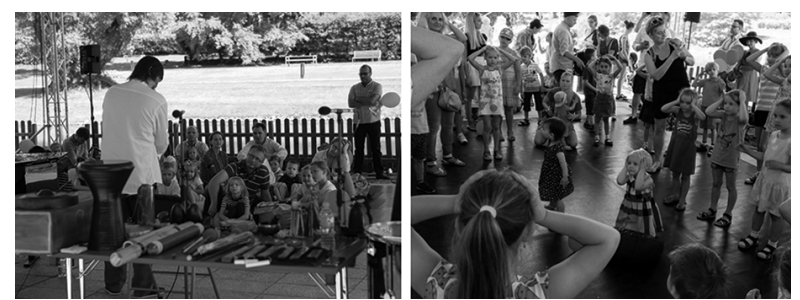

Fig. 12

Children's Day - Żelazowa Wola (05.06.2016)

Percussion workshops (photo byWaldemar Kielichowski)

Music games (photo byWaldemar Grzędziński)

(C) NIFC Archive

Of course, an active approach to artistic and musical tasks is a key issue for schools, faculty, and mass events during all the activities.

\section{Conclusions}

1. Globalization and the related pauperization of artistic tastes is a process that cannot be taught directly. It is possible and necessary to shape higher aesthetic expectations than those provided by the commercialized entertainment market.

2. An important role is played by artistic education - including music especially — and not by professional musicians, but by general education reaching the majority of society.

3. Art schools and music majors at art colleges should prepare their graduates for educational activities and provide them with tools for shaping common tastes.

4. A separate issue is to educate decision-makers and parents how important music is to developing a child. Music is not a "entertainment for elites", but an important element of shaping psychoindividuality and intellectual ability of children and teens. 